\title{
ECONOMIC DEGLOBALIZATION - FROM HYPOTHESIS TO REALITY
}

\author{
Cătălin Postelnicu, Vasile Dinu, Dan-Cristian Dabija
}

\section{Introduction}

Benefits of globalization in the economy of the country is a contentious issue not only in general public but also among academics and professionals of the world economy and international trade, management and marketing, who hold important positions in European or international financial institutions [4]. So far, in most cases, deglobalization has been regarded as a process of diminishing economic interdependence and integration between states [16]. Consequently, the term is widely used to describe several historical periods, when the flows of foreign direct investment (FDI) and the capacity of international trade were declining due to the consequences of regional or global economic crises.

By definition, deglobalization is conceptually set in contrast to the process of globalization, thus failing to admit the multiple connotations of the latter concept. Beginning with the 1980s of the last century, when the third great wave of globalization became a subject of concern, some economists and sociologists implied that they were questioning the positive stance of globalization, considering that it might not be as strong as it seemed and it would not have long-term incidence [20]. Discouraged by the incapacity of globalization to find solutions to some vital issues of the global economy (such as poverty, unemployment, decline and destructuring of entire economic sectors etc.), a series of researchers and practitioners felt compelled to witness the profound degradation of several historically constituted economic and social structures, which, until then, seemed to be unwavering. Accordingly, they swiftly proceeded to the definition and implementation of a new term which, for lack of other notions, was termed "deglobalization".

"Deglobalization" derives from "globalization" by adding the prefix "de"
[16]. The notion permeated the economic discussions without ever having been given a sufficiently clear and commonly accepted definition apparently intended as an antonym. The current global economic evolutions have stated that the globalization process has lost the propelling force it had possessed before the current financial-economic crisis. Thus, periods of relative decline can also occur at times and they can be associated with a deglobalization tendency, specifically with a tendency to reposition the global economy on new coordinates of efficiency and competitiveness. Hence, periods of reversal may possibly lead to deglobalization tendencies with new rules of efficiency and competitiveness.

This situation represents to a certain extent an option for survival and not necessarily a plea for revisiting the age of economic protectionism, specific to many decades of the last century. Such periods in which the process of globalization decreased in intensity, have been known since the second half of the $19^{\text {th }}$ century. They became more numerous throughout the $20^{\text {th }}$ century, especially as a follow-up of the outbreak of the two world wars which immensely destabilized the global economy. They were accompanied by the Great Depression of the 1929-1933s, whose echo died out many years later, but whose effects are persisting nowadays in one form or another [16]. The process of globalisation is closely linked to ideas of neoliberalism, laissez-faire economy, free market and it is not the result of regulated state policy [3].

\section{Measuring Deglobalization}

Indeed, one of the constant issues of economic theory and practice refers to the method of measuring the deglobalization phenomenon. Similar to globalization, a set of indices can be taken into account in order to reveal the 
facets of the phenomenon of deglobalization. Contemporary economic research [16] postulates that the process of deglobalization can be best highlighted by watching at least three main economic flows, such as:

- Dynamics of imports and exports of goods and services at a global or regional level, as an expression of international commerce.

- Dynamics of expats' money remittance.

- Inflows and outflows brought by foreign direct and portfolio investments.

Monitoring these three macroeconomic components alone does not give a clear enough picture of the globalization process. The analysis must rest on additional information, such as of changes in technology transfer, evolution of tariffs and non-tariff barriers to trade, restrictions imposed by some states on the free movement of labour, elaboration of administrative acts meant to encourage the purchase and consumption of local goods, subsidies offered to protect the agricultural sector etc. [6]. Many of these leverages are activated especially during periods of economic crisis. In this regard, conclusive evidence follows from the reaction of highly developed countries (Japan, USA, Germany, France, UK etc.) to the negative effects of the economic-financial crisis between 2008 and 2010. These have contributed in different ways to some drawback in the process of globalization. This may be connected with stagnation or even recession in some economies (currently observed in some states of the European Union (EU), and also in other regions of the global economy). Still, it would be wrong to attribute these changes only to economic crises. Other events, such as natural and economic disasters, major armed conflicts, etc., can contribute to this development.

Some researchers [11], [14], [30] point out in recent studies that within the last 10-20 years, deglobalization phenomena have in fact surfaced more intensively at a global level. At least the last wave of globalization shows atypical tendencies when compared to the former ones [24]. The existence of such a process was confirmed in 2013, when the Swiss Economic Institute (SEI, Zürich, Switzerland) published the so-called Index of Globalization [25]. Basically, this index covers a wider range of issues, including not only the economic but also the social, political and cultural globalization. The index highlights the globalization level of a national economy, taking into consideration the fore mentioned main economic flows, as well as the macroeconomic policy instruments fostered by governments.

Even if the phenomenon of globalization is very difficult to capture in numbers and tables [4], some authors point out that the globalization index is based on 25 variables [21], for 1970-2011 and calculated for 207 countries [23]. This allows for indirect observation of the deglobalization process at certain periods of time. While the social dimension reflects the extent of dissemination of information and ideas, the political one refers to the level of political cooperation between states, but undoubtedly the most important dimension remains the economic one, as it helps in estimating some of the consequences of the economic phenomena on the global market [12].

The necessary data for the index are available up to 2011. The analysis focuses on the consequences of the most recent economic-financial crisis on the slowdown of the globalization process. In our opinion, such a process could be considered a start for deglobalization. Still, its effects would be shortterm. The relative slowdown of the globalization process was mainly experienced by the developed states, e.g. members of OECD. For these countries it was lately reported that the integration process into the world economy had been stagnating. It is very interesting that at the top of the most globalized states, Singapore has achieved the highest score, for a while, and then came second to Ireland [24]. They were closely followed by Belgium and the Netherlands [21]. Other economically developed states further distance themselves from the top - 10, such as: Canada - position 12, Switzerland - 11, Italia 22 , Germany -26 , and the USA barely 32 , on a scale from 1 to 100 [21]. We gradually notice that many developed countries lost their high valuation according to the globalization index eventually recovered after 2010. Developing countries tend to keep the lower positions of the index, weakly anticipating any possibility for major upgrading on the index.

The positions taken by these countries reflect the synergic influence, a conglomerate of all dimensions, without making a clear distinction between them. The synergistic effects of these dimensions are shown in figure 1 , which indicates the evolution of the economic globalization index during 1980-2011. Researchers from the SEI state that the globalization process has 
been visibly slowed down all over the world as a consequence of the current economicfinancial crisis, as compared to the pre-crisis period [25]. Still we don't have to forget that globalization is partially determined by historical context of a country and other specific country conditions [3].

As figure 1 indicates, the globalization index highlights a slight decrease of the pace of economic globalization after 2007. And this is considered to be a trend towards deglobalization. Walden Bello is among those who have noticed the emergence of the economic deglobalization process starting in 2004 [1]. He mentions the so-called "deconstruction", later termed "deglobalization" in a pluralist world [1]. In his opinion, deglobalization describes the means used by developing states in order to promote their local interests, at the cost of the ones endorsed by the supporters of globalization. The deglobalization process is not necessarily connected to the effects created by the economic or financial crises, but it may also be due to other causes (sharp drop in global demand, natural disasters, armed conflicts etc.). In support of his claims, Bello notices the aftershock caused by the Great Depression of 1929-1933 or the Asian financial crisis of 1997 [1]. We think that the current economic depression as a consequence of the financial crisis of 2007 and 2008 confirms his conceptions.

\section{Fig. 1: Evolution of the economic globalization index during 1980-2011, at global level}

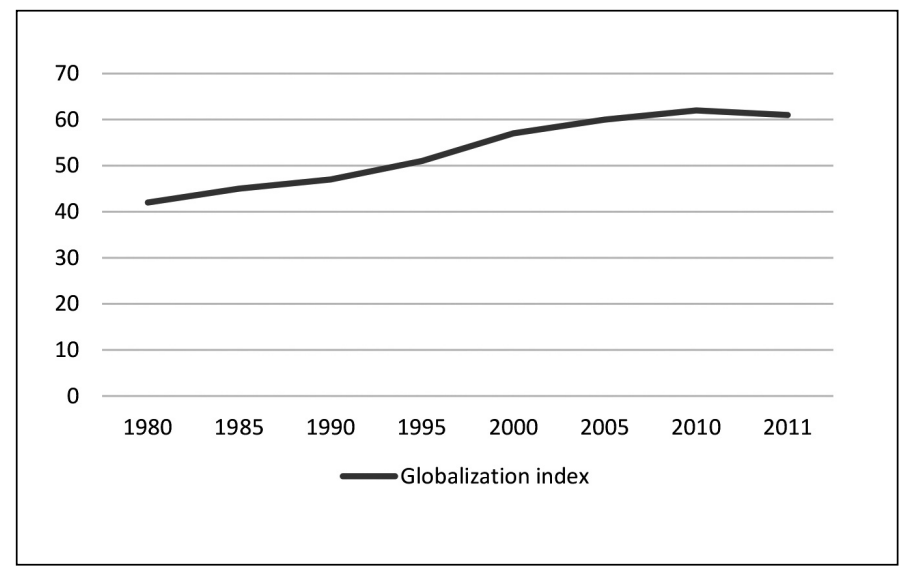

The author underlines that "...the progress of global capitalism is marked not only by the short-term business cycles, but also by the long-term ones, especially by the super-cycles mentioned by Kondratiev a long time ago" [1]. Within such long waves, spreading over 50-60 years, several periods of crisis can distort the globalization process, but also generate factors favourable for globalization. The cyclic character of globalization and deglobalization has also been observed by other researchers [11], over a long period of time. There are interactions with the global circuit of values, as to the size of trade, capital movement, balance of external payments and international technology transfer. Thus, the deglobalization process is opposed to the process of increasing integration of markets and production, which does not only mean less global economy, but also more genuine cooperation between states. This should be based on financial and technological agreements, to secure economic competitiveness of all countries. In the long run, such unbalanced developments can generate intemperate enrichment of some nations, respectively the impoverishment of some others [1].

Hence, deglobalization also means creating leeway so that each country can develop its own economic strategy in accordance with its cultural and social values, its economic necessities and possibilities of sustainable development 
[13]. Human resources like intellectual capital and material resources have to be taken into account. Deglobalization does not necessarily express the manifestation of a destructive strategy dictated by the prolonged crisis faced by global capitalism, as much as it expresses the descending phase of the Kondratiev (K-Wave) Long Wave Cycle [19]. The ascending phase of this cycle began in the 1950s of the last century, and 30 years later it reached a peak-point when the exploitation of obsolete technologies came to an end. This also explains the sequence of several economic crises that have weakened the strength of globalization. Breaking the cycle means finding true alternatives to the current global system, with credible and accepted outcomes by all participants to the international trade in commodities and services.

Bello in fact proposes the idea of a new global economy, although its chances are vague. The deglobalization process is still in its initial phase. It will not end up in autarchy but in new national sovereignty. Deglobalization thus becomes an effort of "reconstruction" which does not involve a withdrawal from the international economy, but its "reorientation", capable of removing the deficiencies of globalized production, all the more so as the many facets of the actual system are fragile and unsustainable [1].

Globalization has for some time become an inevitable phenomenon in the history of humanity. The last decades have been characterized by an enhancement of this phenomenon, due to unprecedented progress in technology, communications, science, transportation, biotechnologies, informatics, material production etc. The current stage of development of the world economy and the evolution of contemporary capitalism transform deglobalization into a myth and not into an actual reality intended to impose itself as a driving force in the near future. Of course, globalization has brought forth advantages and disadvantages. It has allowed the cheapening of many products, it has vastly broadened markets and especially access to them, it has facilitated dissemination of new technologies, thus favouring economic growth [15]. Critics of globalization argue that it has led to the growth of unemployment, it has created multiple environmental problems, it has hugely complicated financial relations which sometimes degenerated into severe crises etc. This situation has led to the necessity of a different kind of globalization, from which all participants in the international division of labour can benefit. Still, the globalization process could not be stopped, because the global economy itself is in full process of transformation. Consequently, globalization does not represent a simple economic event, but a large-scale phenomenon.

Drucker has signalled the fact that in order to be successful in a competitive global market, knowing one's costs is not enough. Every company should be able to determine the costs of the entire economic chain of production which, in most cases, covers a large number of companies spread worldwide [8]. Destructuring such a network already formed through globalization is only a utopian, unattainable and totally ineffective goal. Currently, production, management and distribution are organized in networks. Multinational firms have the capacity to work and act now in real time on a global scale. Certainly, not every economic activity necessarily presents a global feature. Many activities keep their local or regional features. However, the major strategic activities are currently included in a globalized, interconnected, interdependent system, so that whatever happens in the morning in a large North American bank on Wall Street is felt in a very short time in Tokyo, Frankfurt and London. The sophisticated information system based on global communication networks enables very fast responses to any signal coming from any economic or financial "corner" of the world [9]. From this perspective, we think that the effort to create an entirely free global market, as imagined by Bello, is an illusion, a utopia, an unattainable goal in the near future.

The Dutch economist van Bergeijk starts [27] from the observation that, during the last years marked by the recent economic-crisis, international trade has undergone a real collapse, comparable to the one recorded during the Great Depression of the 1930s of the last century. To a certain extent, the researcher overemphasises the international trade aspects during the two periods, as well as the completely different causes that determined its breakdown. Still, van Bergeijk broadly demonstrates that the globalization process mainly caused by the international trade flows can be summarized in two major causes: social and economic risks and uncertainties caused by the crisis. The author warns of the danger of protectionism revival that seems to be "waiting by the corner". 
Therefore, van Bergeijk interprets the decline of international trade to be a clear indication of the deglobalization process of the global economy.

Hillebrand approaches this issue more pragmatically [10], considering that the deglobalization process has started to manifest itself from the period 1913-1950 when, due to the two world wars, the international division of labour was seriously affected, concomitantly with the sometimes excessive assertion of global protectionism [10]. He analysis in detail the long-term effect that deglobalization would have on the developed countries, members of OECD. In order to do this, he creates two scenarios: the one of "deglobalization", understood as a process of reducing the economic interdependence between states (including integration), the other of "globalization" itself. Finally, Hillebrand reaches the conclusion that the GDP per capita in 2035 could be by $23 \%$ smaller in case of "deglobalization" than by continuing economic "globalization" [10]. Concomitantly, the number of people globally living in extreme poverty will increase.

Hence, not only the rich, developed states and the less advanced ones will suffer from deglobalization, but also the society as a whole. The influences and impact would have different proportions. For example, applying the globalization scenario on the USA would raise GDP per capita to 66,150 dollars/year by 2035 , whilst applying the deglobalization scenario would raise GDP per capita only to $60,290 /$ year. Hence, a difference of $-8.9 \%$. In absolute amount, the total GDP of the USA would rise to 24,287 billion dollars if the globalization scenario were applied, as compared to 19,794 billion dollars in case of deglobalization [10]. The situation would look even worse for the EU. Here the difference between the two GDPs would be even more pronounced, amounting to $-21.3 \%$, or $\$ 31,270$ per capita in annual average, in case of the globalization scenario, and only $\$ 24,600$ in case of the deglobalization one [10].

These data confirm that globalization works in tandem with economic development, in contrast to deglobalization which impedes it. More serious is the fact that deglobalization generates instability between states due to weakening the ties of economic interdependence, enhancing the prospect of unwanted economic or trade conflicts. Thus, deglobalization contributes to the reduction of trade and capital flows, negatively affecting economic development. Under the condition of deglobalization (synergistic effects of various uncontrollable factors, drastic reduction of technology transfer, raw materials and innovations, less dependence on foreign capital) states impair their own future due to a decrease of labour productivity. This is the main factor of economic growth and poverty reduction. Autarchic development has therefore become anachronistic at the present stage of development of the global economy, possible only for restricted geographical areas, with very small, isolated states.

\section{Is Deglobalization a Long-Term Phenomenon?}

Careful observation of the evolution of international trade and foreign direct investments (FDI) can help to find out whether deglobalization is a permanent or only a temporary process. The issue of money remittances from expats working abroad is a different question. During the last 20-30 years, a series of major changes have marked the evolution of international trade. This allows us to say that we are confronted with a new stage of development of the global economy, namely deglobalization.

The World Trade Organization (WTO) Report for 2013 enables us to assess the main tendencies in recent world trade, but also several possible scenarios of future evolution [28], [29]. The WTO analysis emphasizes that international trade in commodities and services has experienced notable changes with respect to geographical dispersion, structure and number of agents. These trades have been and are still influenced by a series of major factors such as demography, FDI, technologies involved in the production process, energy sources and the necessity to preserve exploitable natural resources, sustainability of consumption, transportation costs, production of modern means of communication, trade agreements between states. Subsequently, the integrationist pressure has enhanced intensity at rates far beyond global GDP. For example, between 1980 and 2011, the international trade in commodities increased at a rate of over $7 \%$ per year, up to a value of 18 trillion US dollars at the end of the period. Trade services, of about 4 trillion US dollars by the end of 2011 , 
have to be added to this value. In real terms (by removing the influence of the inflation rate and the variation of exchange rates), the international commodity trade rose, between 1980 and 2011, on an almost four times higher level and two times faster than production [29]. Simultaneously, new participants have emerged on the global market scene, such as several developing countries, emerging countries (Central European states and from the former Soviet influence block), as well as rapidly industrializing economies (China, India, Brazil, the Russian Federation, etc.). In 1980, developing economies accounted for $34 \%$ of the world merchandise exports, by 2011 they reached a share of $47 \%$ [29]. China, India, Brazil, Mexico, etc., particularly are outstanding among them.

The spread of modern technology, export specialization and increasing factor mobility accompany a vast amplification of trade between "South-South" and "North-South". In recent years, many states have been able to better exploit comparative advantages, especially as a natural consequence of the globalization process [16]. The increase of production has played a decisive role for economic growth, although the connection between this and the demographic factor has become more complicated in certain geographical areas. We estimate that in this situation we can no longer speak of a "collapse" of international trade, or of a clear deglobalization tendency due to the decline in international trade between 2008 and 2009.

All data submitted by WTO have indisputably proven the opposite. Figure 2 indicates that the capacity of world commodity export has followed an upward trend between 1990 and 2012, with a slight decline between 2008 and 2009 caused by the financial and economic crisis. The same conclusion can be drawn from the growth rates of GDP, the global imports and exports (table 1).

\section{Fig. 2: Dynamics of world commodity exports 1990-2011 $(1990=100)$}

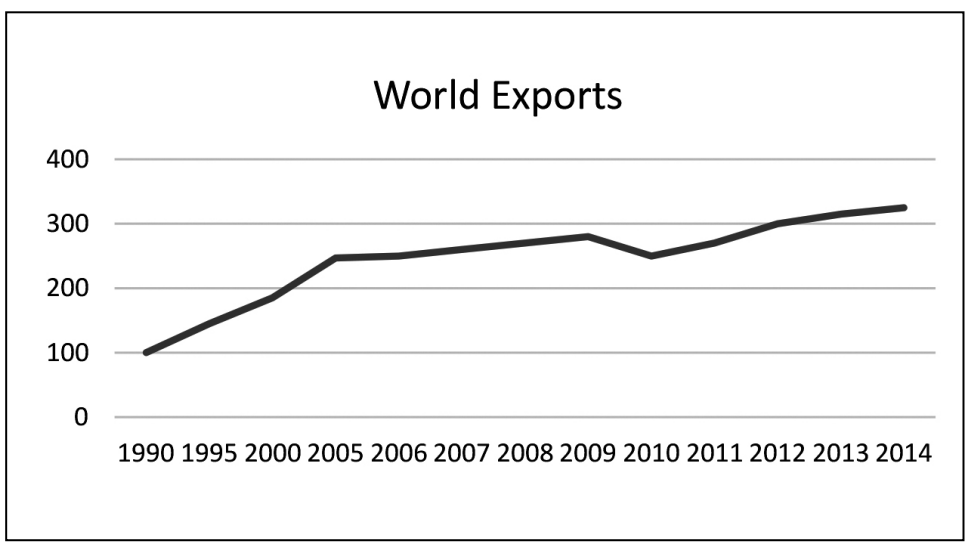

Source: [26]

2009 indeed proved to be the most unfortunate year, not only for the gross world product (GWP), but also for the international commodity trade, measured by exports and imports. Although 2010 indicated the prospect of a fast recovery, 2011 was strongly affected by the sovereign debt crisis in Europe and contractions in the supply of goods caused by certain natural disasters (earthquakes, floods, etc.) or social unrest in some Arab countries (Libya, Tunisia, Egypt). 


\begin{tabular}{|c|c|c|c|c|c|c|c|c|c|}
\hline \multirow[t]{3}{*}{ Tab. 1: } & \multicolumn{9}{|c|}{$\begin{array}{l}\text { Gross domestic product (GDP) and export - global import of goods } \\
\text { (annual increase / decrease in \%) }\end{array}$} \\
\hline & \multicolumn{3}{|c|}{ GDP } & \multicolumn{3}{|c|}{ Export } & \multicolumn{3}{|c|}{ Import } \\
\hline & 2009 & 2010 & 2011 & 2009 & 2010 & 2011 & 2009 & 2010 & 2011 \\
\hline Global & -2.6 & 3.8 & 2.4 & -12 & 13.8 & 5.0 & -12.9 & 13.7 & 4.9 \\
\hline
\end{tabular}

Source: World Trade Organization, World Trade Report 2012, p. 20.

\section{Tab. 2: Growth rates of GDP and commodity trade recorded by developed countries as compared to developing countries}

\begin{tabular}{l|c|c|c|c|c|c|c|c|c} 
& \multicolumn{3}{|c|}{ GDP } & \multicolumn{3}{c|}{ Export } & \multicolumn{3}{c}{ Import } \\
\cline { 2 - 11 } & $\mathbf{2 0 0 9}$ & $\mathbf{2 0 1 0}$ & $\mathbf{2 0 1 1}$ & $\mathbf{2 0 0 9}$ & $\mathbf{2 0 1 0}$ & $\mathbf{2 0 1 1}$ & $\mathbf{2 0 0 9}$ & $\mathbf{2 0 1 0}$ & $\mathbf{2 0 1 1}$ \\
\hline $\begin{array}{l}\text { Developed } \\
\text { states }\end{array}$ & -4.1 & 2.9 & 1.5 & -15.1 & 13.0 & 4.7 & -14.4 & 10.9 & 2.8 \\
\hline $\begin{array}{l}\text { Developing } \\
\text { states }\end{array}$ & 2.2 & 7.2 & 5.7 & -7.4 & 14.9 & 5.4 & -10.5 & 18.1 & 7.9 \\
\hline
\end{tabular}

Source: World Trade Organization, World Trade Report 2012, p. 20.

It is a remarkable fact that the developing economies have been less affected by the adverse consequences of the recent economic and financial crisis, as compared to the developed countries (table 2).

The most important emerging economies with strong economic potential such as China, India, Brazil, the South African Republic, the Russian Federation, Mexico and others, have had an important role in this development. The five largest exporters in 2011 were China with 1.9 trillion US dollars or $10.4 \%$ of world exports, the U.S.A. (1.48 trillion US dollars), Germany (1.47 trillion US dollars), Japan (833 billion US dollars), the Netherlands (660 billion US dollars). EU-27 was ranked on top of exporters by 2.13 trillion US dollars in 2011 [28]. Within the next years, we expect that they will be the main promoters of world trade in commodities.

As to the capital flows caused by FDI, they were clearly less present when compared to the previous years, reaching a total of 1.35 trillion US dollars in 2012. The severe reduction (by approximately 18\%) was in sharp contrast with the evolution of GDP and international trade which recorded global increases [26]. This decrease reflects the deficiencies of the global economy and the uncertainties caused by the recent crisis, which determined the investors to become more cautious. The report presented by UNCTAD states that the recovery of confidence in the business environment will take longer than economists have expected. Though macroeconomic conditions improved, FDI might record a considerable leap, reaching 1.6 trillion US dollars in 2014 and 1.8 trillion US dollars in 2015 [26] despite several risks. This demonstrates the weakness of the global financial system, the possible deterioration of the macroeconomic situation in some geographical areas, as well as the slow recovery of investors' confidence. As shown by the data analysis included in figure 3 , there was a drop in FDI after their spectacular increase from 2004 to mid-2007, due to the economic-financial crisis. After 2009 a slowing rate of decline can be observed, the FDI volume recording several oscillations due to the slow revival of the global economy.

The top positions of the largest investing economies are still occupied by the same developed countries, to which several emerging countries have been added. Thus, the top places were represented in 2012 by the USA (329 billion US dollars), Japan (123), China (84), the United Kingdom (71), Germany (67), Canada (54), the Russian Federation (51), Switzerland (44), France (37), Sweden (33), South Korea (33), Italy (30), and so on [26]. These economies will maintain the positive trend until and after 2015, the world stock of capital investments continuing to rise from 14.706 billion US dollars, the value during the 2005-2007 pre-crisis period, to 22.593 billion US dollars in 2012 [26]. 


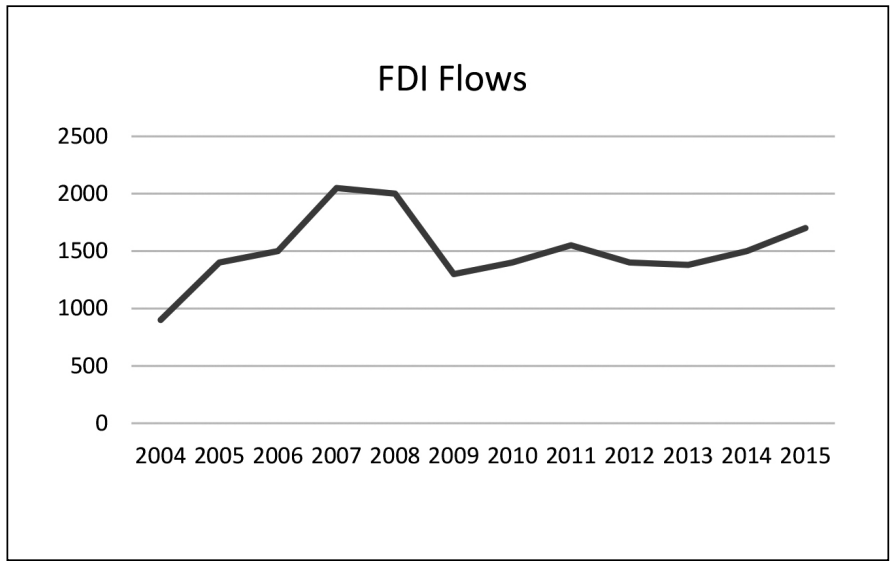

Though some fluctuations occurred over time, FDI flows will continue their upswing in the following period, the idea of deglobalization remaining still an illusion from this point of view. Of course, both the emitting and the receiving countries will become more selective towards the incorporation of these investments with respect to different economic goals. In addition, we should not overlook the fact that the risk of protectionism in the investment field has not altogether disappeared, especially in what certain strategic sectors are concerned (hightech industries, innovation, energy, etc.).

\section{Conclusions}

Globalization has reached a stage of development where the fragmentation of production and the international dispersion of economic activities have reached unimaginable shares in the not too distant past. At present, almost $60 \%$ of the global trade consists of intermediate goods and services that are incorporated into various stages of material production. This has led to the creation of a highly complex network that was included into what we may call "the global value chain". Nowadays, this global value chain has become the main feature of the world economy. Globally, about $28 \%$ of the total exports correspond to the added value that was first imported, and then incorporated into products and services to be exported again [26].
Fragmentation of production has reached such high levels in some industries (automobile, electronics, chemistry, IT, etc.), that these productive chains can no longer be interrupted, without seriously impairing costs and economic efficiency on a whole. Each country aims at taking a position as favourable as possible in this global production chain, and strives not to isolate itself. To speak under such circumstances about the necessity of deglobalization means to condemn an economy "ab initio" to underdevelopment, backwardness, and eventually to a drop-out from the map of the civilized world. Deglobalization presented as a new possible version of the international division of labour, only means the annihilation of the synergistic effects created by globalization through investments and trade. Ultimately, the relevance of these two major vectors of development cannot be evidenced by deglobalization, but by international economic integration.

Under certain circumstances, the cyclic nature of economy could eventually affect all players on the market. This, on the other hand, could entitle us to read it as a positive outcome of deglobalization. The current economic crisis is global, without offering global solutions. On the contrary, each nation looks for its own solutions. Consequently, the global crisis is practically understood more as the sum-total of several local crises. When speaking of "local solutions to a global crisis", we are also dealing with a tendency towards deglobalization. 


\section{References}

[1] BELLO, W. Deglobalization: Ideas for a New World Economy. Zed Books, 2004. ISBN 9781842773055.

[2] CHEBEŇ, J., HUDÁČKOVÁ, L. Influence of the global economic crisis on consumer behaviour in Slovakia. In: Working papers Fakulty mezinárodních vztahů. Praha: Nakladatelství Oeconomica. Vysoká škola ekonomická v Praze. 2010, Iss. 9, pp. 5-19.

[3] CHEBEŇ, J. Faktory vplývajúce na zmenu marketingových stratégií v období globalizácie. In: Hradecké ekonomické dny 2006: podnikání a rozvoj regionu. Sborník príspěvkủ z vědecké konference, Hradec Králové, 7. a 8. února 2006. Hradec Králové: Gaudeamus, 2006. pp. 179186. ISBN 80-7041-895-8.

[4] CHEBEŇ, J. Influence of globalization on agrarian sector in Slovakia. In: SGEM conference on political sciences, law, finance, economics \& tourism: International multidisciplinary scientific conferences on social sciences \& arts. 2014. pp. 349-356.

[5] COHEN, D. La mondialisation et ses enemis. Paris: Grasset, 2004. ISBN 2-2466-6401-2.

[6] DINU, V. The Protection of the Consumers Rights in an Era of Technological Changes and Globalization. Amfiteatru Economic. 2014, Vol. 16, Iss. 36, pp. 449-450. ISSN 1582-9146.

[7] DREHER, A., GASTON, N., MARTENS, P. Measuring Globalization - Gauging Its Consequences. New York: Springer, 2008. ISBN 978-0-387-74069-0. DOI: 10.1007/978-0387-74069-0.

[8] DRUCKER, F.P. Management Challenges for the 21st Century. New York: Harper Business, 1999. ISBN 978-0887309991.

[9] DUMITRU, M., ALBU, N., DUMITRU, V.F., ALBU, C.N. Practices Regarding the Forms of Communication with the Consumers used by a Multinational Company at Global and Local Level. Amfiteatru Economic. 2014, Vol. 16, Iss. 35, pp. 41-57. ISSN 1582-9146.

[10] HILLEBRAND, E.E. Deglobalization Scenarios: Who Wins? Who Loses? Global Economy Journal. 2010, Vol. 10, Iss. 2, pp. 1-21. ISSN 1524-5861. DOI: 10.2202/15245861.1611.

[11] KARUNARATNE, N.D. The GlobalizationDeglobalization Policy Conundrum. Modern Economy. 2012, Vol. 3, Iss. 4, pp 373-383. ISSN 2152-7245. DOI: 10.4236/me.2012.34048.

[12] KOCOUREK, A., BEDNÁŘOVÁ, P., LABOUTKOVÁ, Š. The Linkages between
Human Development and Economic, Social, and Political Dimension of Globalization. E+M Ekonomie a Management. 2013, Vol. 16, Iss. 2, pp. 10-21. ISSN 1212-3609.

[13] MINIC, T., PETROVIC, B., ILIC, O. A new approach to Integral Information System of a Company for Business and Sustainable Development. Amfiteatru Economic. 2013, Vol. 15 , Special Iss. 7, pp. 769-783. ISSN 15829146.

[14] MISKIEWICZ, J., AUSLOOS, M. Has the World Economy Reached Its Globalization Limit? Physica A. 2010, Vol. 389, Iss. 4, pp. 797-806. ISSN 0378-4371. DOI: 10.1016/j. physa.2009.10.029.

[15] POSTELNICU, C., DABIJA, D.C. Transfer and Diffusion of New Technologies within the Supply Chain of multinational companies with operations in to Developing Economies A Contemporary Approach. In: VĂDUVA, S., ANDREW, T. (Eds.). Geopolitics, Development, and National Security. Springer Publishing House, 2015. ISBN 978-3-319-12685-2. DOI: 10.1007/978-3-319-12685-2_3.

[16] POSTELNICU, G., POSTELNICU, C. Globalizarea economiei. București: Editura Economică, 2000. ISBN 973-590-414-4.

[17] RUSSELL, J. (Ed.). Deglobalization. Miami: Book on Demand, 2012. ISBN 5512591924.

[18] SAPIR, J. La demondialisation. Paris: Seuil, 2011. ISBN 978-2021034981.

[19] SOLOMOU, S. Phases of Economic Growth, 1850 - 1975. Kondratieff Waves and Kuznets Swings. Cambridge: Cambridge University Press, 1990. ISBN 978-0521389044. [20] STRAW, W., GLENNIE, A. The Third Wave of Globalization. In: IPPR Review on the Future of Globalization. London: Institute for Public Policy Research, 2012.

[21] SWISS ECONOMIC INSTITUTE. $2014 \mathrm{KOF}$ Index of Globalization [online]. Zurich: SEI, 2014 [cit. 2014-06-10]. Available from: http://globalization.kof.ethz.ch/media/filer_public/2014/04/15/ rankings_2014.pdf.

[22] SWISS ECONOMIC INSTITUTE. Press Release, KOF Index of Globalization [online]. Zurich: SEI, 2014 [cit. 2014-05-15]. Available from: http://globalization.kof.ethz.ch/.

[23] SWISS ECONOMIC INSTITUTE. 2014 KOF Index of Globalization [online]. Zurich: SEI, 2014 [cit. 2014-05-16]. Available from: http://globalization.kof. ethz.ch/media/filer_public/2014/04/15/ variables_2014.pdf. 
[24] SWISS ECONOMIC INSTITUTE. Press Release, KOF Index of Globalization 2014: Switzerland no Longer Among the Top Ten [online]. Zurich: SEI, 2014-04-16 [cit. 201405-05]. Available from: http://globalization.kof. ethz.ch/media/filer_public/2014/04/16/press_ release_2014_en.pdf.

[25] SWISS ECONOMIC INSTITUTE. Press Release, KOF Index of Globalization 2013. Friday 1 March 2013.

[26] UNCTAD. World Investment Report 2013, Global Value Chains: Investment and Trade for Development. Geneva: United Nations, 2013.

[27] VAN BERGEIJK, P.A.G. On the Brink of Deglobalization. Edward Elgar, 2010. 192 p. ISBN 978-1849804110. DOI: $10.4337 / 9781849805803$.

[28] WORLD TRADE ORGANIZATION. World Trade Report 2012, Trade and Public Policies: A Closer Look at Non-Tariff Measures in the 21st Century. Geneva: WTO, 2012.

[29] WORLD TRADE ORGANIZATION. World Trade Report 2013, Factors Shaping the Future of World Trade. Geneva: WTO, 2013.
[30] ZEHRA, N. The Realist State and Deglobalization. In: Policy Perspectives. No. 2 July - December 2011.

Assoc. Prof. Cătălin Postelnicu Babeș-Bolyai University Cluj-Napoca Department of Economics catalin.postelnicu@econ.ubbcluj.ro

Prof. Vasile Dinu

Bucharest University of Economics

Faculty of Business and Tourism Department of Business, Consumer Sciences and Quality Management dinu_cbz@yahoo.com

Assoc. Prof. Dan-Cristian Dabija Babeș-Bolyai University Cluj-Napoca Department of Marketing cristian.dabija@econ.ubbcluj.ro 


\section{Abstract}

\section{ECONOMIC DEGLOBALIZATION - FROM HYPOTHESIS TO REALITY}

\section{Cătălin Postelnicu, Vasile Dinu, Dan-Cristian Dabija}

Lately, a new term is used in international economic literature, namely "de-globalization" which has already sparked off numerous debates. As expected, some economists were quick to adopt it unhesitatingly, but others have labelled it as "absurd", "superficial", "simple", "anachronistic" and even "counterproductive". In fact, there are two diverging processes opposed to each other, both worth mentioning. First - globalization - with its multiple meanings and definitions, and the second - deglobalization - which is just beginning to find a place within the confines of concepts used in international economics literature. The issue is not to treat them only as antonyms, but rather to demonstrate the causal relation between them. We consider trying to measure deglobalization as an important step in determining the true meaning of such a phenomenon, or if it is real. Also, would be interesting to find out if deglobalization is really a long lasting trend, or just a short term turn in the evolution of the world economy. Using the "globalization index" and its components as a tool in this direction could be one of the potential solutions in defining the meaning of the new and complex changes which tends to shape the international economic relations and, after all, the international business environment. Although it is admitted not being a perfect tool, it could be a starting point in studying such a vast change. Therefore, the motivation of this article is to contribute to theoretical debates that bear on this new term, given that, as in the case of globalization itself, economists have not yet reached a consensus on the definition.

Key Words: Globalization, deglobalization, international trade, foreign direct investment (FDI), economic integration.

JEL Classification: F14, F23, F6, F21.

DOI: 10.15240/tul/001/2015-2-001 